\title{
Unexpected Formation of Hexasubstituted Arenes through a Twofold Palladium-Mediated Ligand Arylation
}

Corin C. Wagen, Bryan T. Ingoglia, and Stephen L. Buchwald*

Department of Chemistry, Massachusetts Institute of Technology, Cambridge, MA 02139, United States

Abstract: A rearrangement reaction of biarylphosphine-supported Pd(II) complexes was employed to synthesize 1,3,5triaryl 2,4,6-triisopropylbenzene compounds, a class of molecules that has not previously been reported. The strain of the central hexasubstituted ring was investigated via X-ray crystallography.

Hexasubstituted arenes have been a topic of interest in organic chemistry due to their high steric strain, which makes them appealing targets for the study of conformational dynamics and aromaticity, ${ }^{1-4}$ as well as their rigidity, which allows for enforcement of unique molecular architectures..$^{5-7}$ Traditionally, hexasubstituted benzene rings have been synthesized through metalcatalyzed $[2+2+2]$ alkyne cyclotrimerization, a reaction that has enabled the synthesis of remarkably strained molecules but often times requires harsh conditions and is predominantly employed to access $C_{3}$-symmetric products. ${ }^{1,8}$ Despite advances in cross-coupling ${ }^{9,10}$ and cycloaddition chemistry, ${ }^{11,12}$ the controlled synthesis of less symmetric hexasubstituted arenes with bulky substituents remains challenging. Here, we report a palladium-mediated dearomative rearrangement that enables the synthesis of 1,3,5-triaryl 2,4,6triisopropylbenzenes, a previously unknown class of strained hexasubstituted arenes.

While attempting to prepare triaryl phosphine $\mathbf{2}$ through our previously reported dearomative ligand rearrangement, ${ }^{13,14}$ we were surprised to find a mixture of mono- and bis-arylated products $\mathbf{2}$ and $\mathbf{3}$, favoring $\mathbf{3}$ in a 56:44 ratio as determined by ${ }^{31} \mathrm{P}$ NMR spectroscopy (Figure 1).
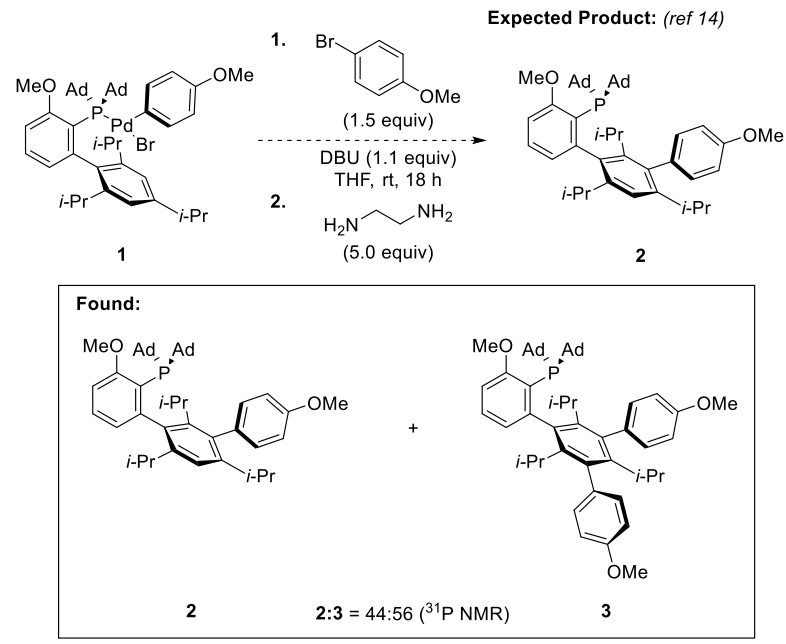

Figure 1. Discovery of a synthetic route to the hexasubstituted arene $\mathbf{3}$.
The difficulty of separating mono- and bis-arylated products $\mathbf{2}$ and $\mathbf{3}$ prompted us to search for conditions that would favor the complete formation of $\mathbf{3}$. By increasing the equivalents of aryl halide and base utilized, heating the reaction mixture, and extending the reaction time, we obtained a mixture of predominantly $\mathbf{3}(96 \%)$ along with trace amounts of $2(4 \%)$. The material could be purified by recrystallization to give $313 \mathrm{mg}$ of $\mathbf{3}$ in $69 \%$ yield (Figure 2).

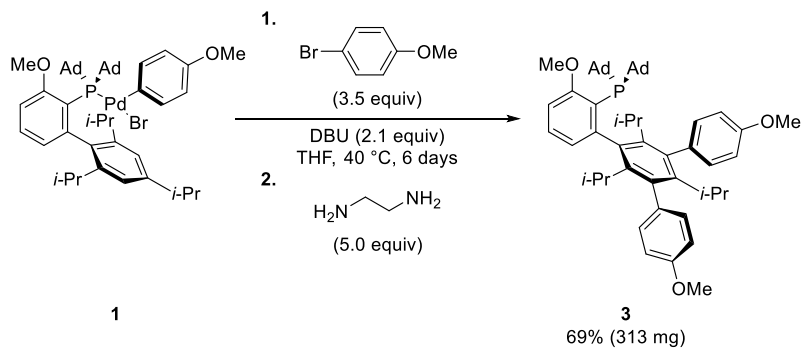

Figure 2. Optimized synthesis of $\mathbf{3}$.

Attempts to use alternative solvents (e.g., dioxane, toluene) or further increase the reaction temperature led to increased levels of unidentified decomposition products. Efforts to use a catalytic quantity of Pd resulted in only a single-turnover to a stoichiometric amount of product, although previous reports indicate that ligand exchange can occur at the $\mathrm{Pd}(\mathrm{II})$ oxidation state. ${ }^{15}$ 


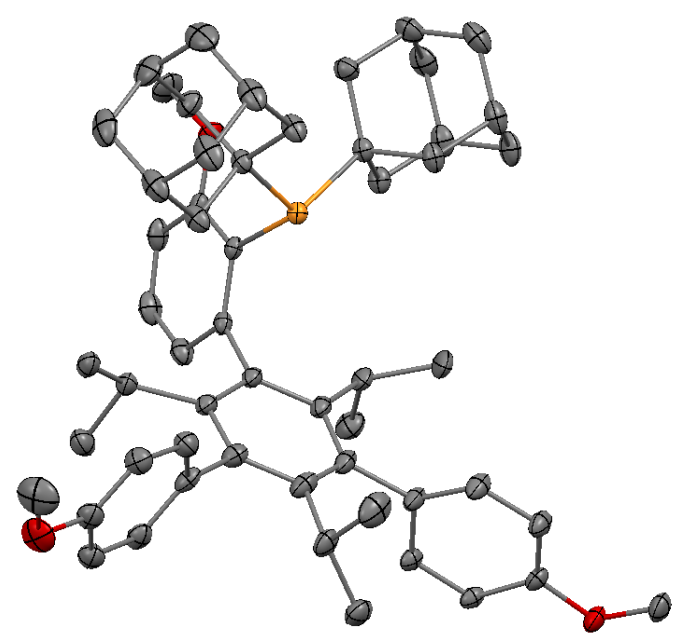

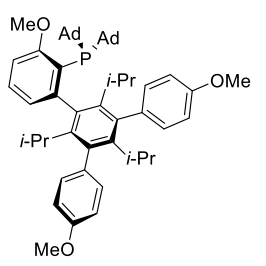

\section{A. Angular Distortion:}

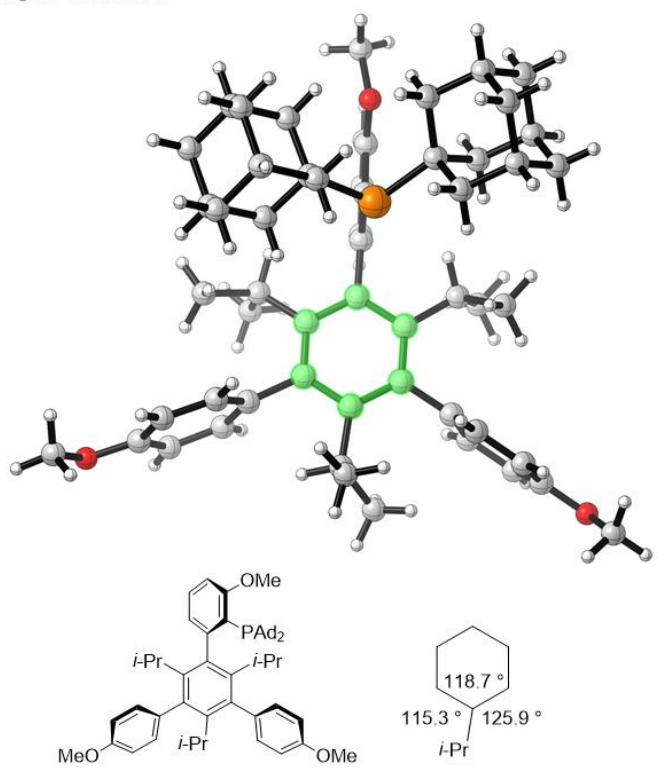

Figure 3. Crystal structure of 3. Hydrogen atoms have been omitted for clarity, and thermal ellipsoids are depicted at $50 \%$ probability.

Crystallographic analysis of $\mathbf{3}$ confirmed the structure as resulting from the bis-arylation of $\mathbf{1}$ (Figure 3 ). The hexasubstituted middle benzene ring showed signs of strain-induced distortion caused by the close isopropyl-aryl and isopropyl-adamantyl contacts. In particular, one isopropyl group was bent approximately $5^{\circ}$ away from ideal $120^{\circ}$ bond angles (Figure 4a); the magnitude of this deformation is interesting given that typical $s p^{2}$ and $s p^{3}$ carbon bond angles differ by only $11^{\circ}$. One of the middle ring's dihedral angles was found to be $8.26^{\circ}$, comparable to the out-of-plane distortion observed in 1,2-diadamantylbenzene (Figure $4 \mathrm{~b}$ and $4 \mathrm{c}$ ). ${ }^{16}$
B. Dihedral Distortion:

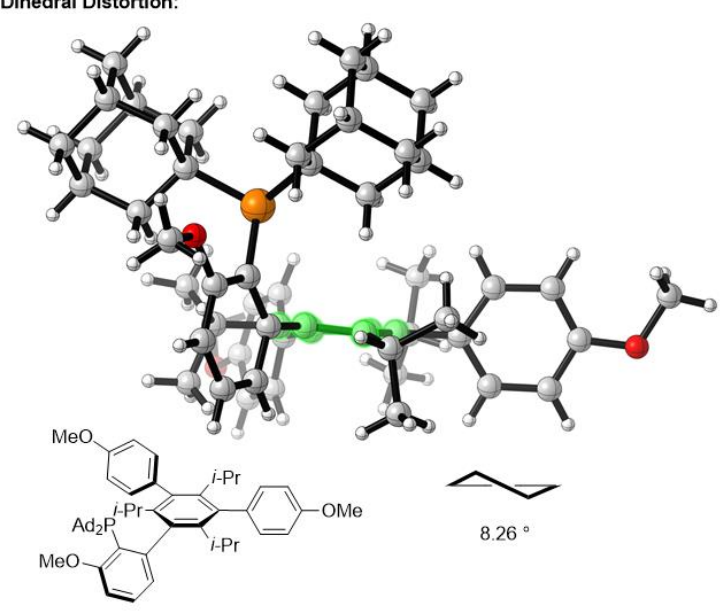

C. ORTEP View of Distortion:

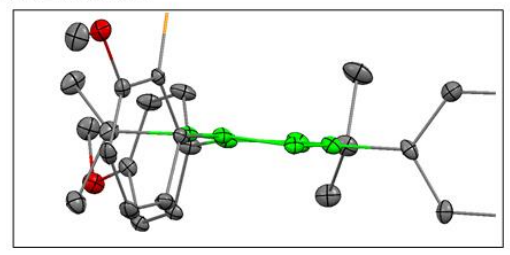

Figure 4. Distortion in the middle ring (highlighted in green) of hexasubstituted arene 3, including (A) angular distortion and (B) dihedral distortion. Key bond angles are illustrated below the figures. The torsion in the middle ring has also been depicted in ORTEP (C) to better show the deviation from planarity. (For clarity, hydrogen atoms and one isopropyl group have been omitted and thermal ellipsoids depicted at $30 \%$ probability.)

Previous results from our group indicated that highly substituted ligands can enhance the Lewis acidity of palladium and enable $\mathrm{C}-\mathrm{N}$ couplings using weak organic bases. ${ }^{17}$ Unfortunately, initial attempts to use complexes derived from $\mathbf{3}$ as catalysts met with little success. $\mathbf{3}$ did not cleanly form a $\left[(\mathrm{L}-\mathrm{Pd})_{2} \cdot(\mathrm{COD})\right]$ precatalyst, ${ }^{18}$ and 
formed oxidative addition complex 4 in only $26 \%$ yield. $^{19}$ This complex was found to be ineffective at catalyzing a model C-N coupling (Figure 5). ${ }^{17}$ This result may be due to the substantial steric bulk of $\mathbf{3}$, which could impair oxidative addition or prevent amine binding.

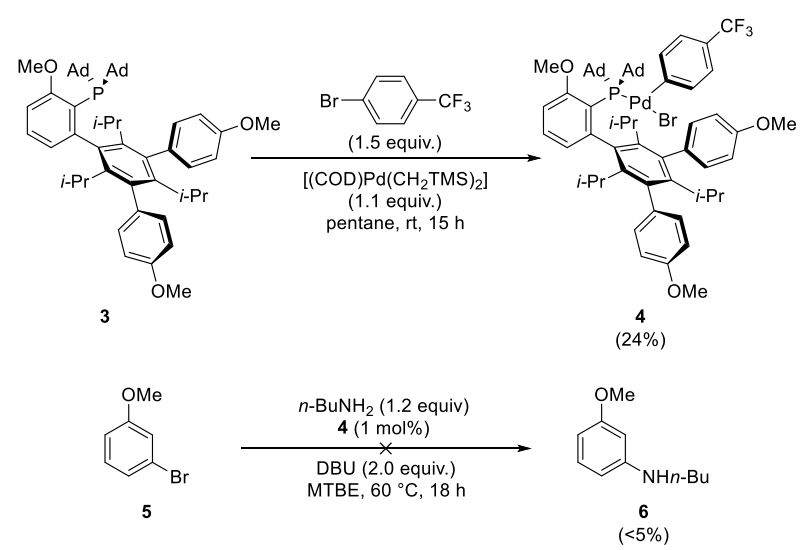

Figure 5. Synthesis of a precatalyst derived from $\mathbf{3}$ and its subsequent use as a catalyst for $\mathrm{C}-\mathrm{N}$ coupling

The optimized conditions for the preparation of $\mathbf{3}$ were found to be amenable to the synthesis of other hexasubstituted arenes. Consistent with previous results, ${ }^{14}$ electron-poor aryl halides reacted only slowly and often gave inseparable mixtures of mono- and bisarylation (see the Supporting Information for details); electron-rich arenes were therefore used to drive the reaction towards completion. By forming the $\operatorname{Pd}(\mathrm{II})$ oxidative addition complex with one aryl halide and performing the rearrangement in the presence of a second aryl halide, two distinct aryl groups could be selectively installed, as shown by the synthesis of unsymmetrical arenes $\mathbf{8}$ and $\mathbf{1 0}$ (Figure 6). Similarly, the di-tert-butyl ligand $t$-BuBrettPhos could be doubly arylated to give hexasubstituted di-tert-butyl phosphine 10, demonstrating that adamantyl substitution on phosphorus is not required for this rearrangement. ${ }^{14}$

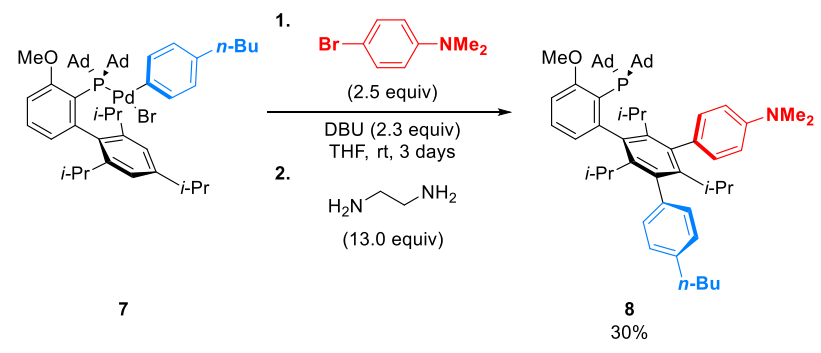

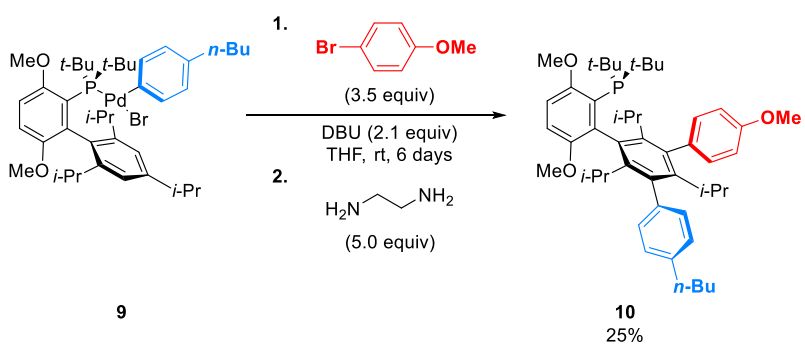

Figure 6. Sequential double arylation allows access to unsymmetrical arenes.

In cases in which we wish to prepare ligands with only a single substituent installed, we felt that a sacrificial aryl halide could be used to block the second arylation. For example, $\mathrm{Pd}(\mathrm{II})$ complexes derived from 2bromothiophene proved recalcitrant towards rearrangement under the standard reaction conditions: accordingly, monoarylated product $\mathbf{2}$ could be synthesized cleanly by using 2-bromothiophene to trap nascent $\operatorname{Pd}(0)$ (Figure 7).

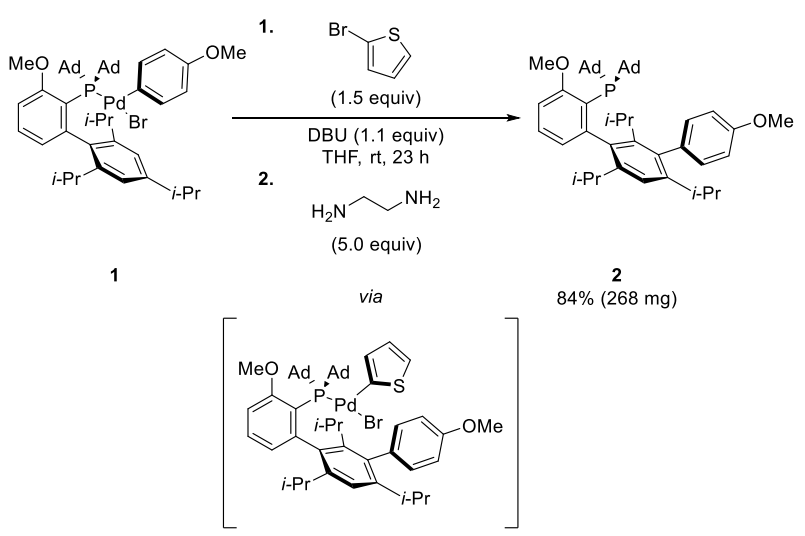

Figure 7. Synthesis of 2 through the use of 2bromothiophene as a "trap" for $\operatorname{Pd}(0)$

In conclusion, we have shown that di-tert-butyl and diadamantyl monophosphine ligands can be converted to highly strained hexasubstituted arenes through a double dearomative rearrangement and demonstrated the synthesis of several such arenes. Currently, the requirement for a bulky ortho-dialkylphosphinobenzene substituent limits the generality of this method. However, the extreme steric congestion of the products accessible by this strategy suggests that a mechanistically analogous transformation employing a more practical directing group may be of considerable interest.

\section{EXPERIMENTAL SECTION:}

\section{General Reagent Information:}

Commercial solvents and reagents were purchased from Aldrich Chemical Company, Strem Chemicals, Acros 
Organics, Alfa Aesar, Combi Blocks, Oakwood Chemical, Oxchem, and Chem-Impex and used as received, with the following exceptions. Anhydrous MTBE was purchased from Aldrich Chemical Company in Sure-Seal ${ }^{\mathrm{TM}}$ bottles, sparged with argon for $1 \mathrm{~h}$, and stored in a nitrogen-filled glovebox. Toluene, tetrahydrofuran (THF) and $\mathrm{CH}_{2} \mathrm{Cl}_{2}$ were purchased from J.T. Baker in CYCLE-TAINER ${ }^{\circledR}$ solventdelivery kegs and vigorously purged with argon for $2 \mathrm{~h}$, followed by passing it under argon pressure through two packed columns of neutral alumina. Copper (I) chloride was stored in a nitrogen-filled glovebox. Large reaction tubes (36 mL capacity; 20 x 150 mm, Part No. 14-959-37C), medium reaction tubes $(25 \mathrm{~mL}$ capacity, $20 \times 125 \mathrm{~mm}$, Part No. 14959-37A), small reaction tubes (8 mL capacity, 13 x 100 mm, Part No. 14-959-35C), large/medium screw-caps (Kimble-Chase, Open Top S/T Closure, Part No. 7380418400), small screw caps (Thermo Scientific, Part No. C401566), large/medium septa (Thermo Scientific PTFE/silicone, Cat No. B7995-18), and small septa (Thermo Scientific PTFE/Silicone, Cat No. C4015-60) were purchased from Fischer Scientific. Compounds were purified using a Biotage ${ }^{\circledR}$ Isolera system, employing polypropylene cartridges preloaded with silica gel (Silicycle SilaFlash ${ }^{\circledR}$ F60 silica gel) or with new Biotage ${ }^{\circledR}$ SNAP cartridges, unless otherwise noted. Samples were eluted using a flow rate of $50-100 \mathrm{~mL} / \mathrm{min}$, with detection by UV (254 nm). Analytical thin-layered chromatography (TLC) was performed using glass plates pre-coated with silica gel ( $0.25 \mathrm{~mm}, 60 \AA$ pore size) impregnated with a fluorescent indicator $(254 \mathrm{~nm})$. TLC plates were visualized by exposure to ultraviolet light (UV). Di(1-adamantyl)chlorophosphine ${ }^{20}$ and $\left[(\mathrm{COD}) \mathrm{Pd}\left(\mathrm{CH}_{2} \mathrm{TMS}\right)_{2}\right]^{21}$ were prepared according to literature procedures.

\section{General Analytical Information:}

Compounds were analyzed by ${ }^{1} \mathrm{H},{ }^{13} \mathrm{C},{ }^{19} \mathrm{~F}$, and ${ }^{31} \mathrm{P}$ nuclear magnetic resonance (NMR) spectroscopy where appropriate. NMR spectra were recorded on a Bruker Avance Neo-400 MHz spectrometer, a Bruker Avance Neo$500 \mathrm{MHz}$ spectrometer, and a Bruker Avance Neo-600 MHZ spectrometer. ${ }^{1} \mathrm{H}$ and ${ }^{13} \mathrm{C}$ spectra were calibrated using residual solvent as an internal reference $\left(\mathrm{CDCl}_{3}: \delta 7.26 \mathrm{ppm}\right.$ and $\delta 77.16 \mathrm{ppm}$, respectively; $\mathrm{C}_{6} \mathrm{D}_{6}: \delta 7.16 \mathrm{ppm}$ and $\delta 128.1$ ppm, respectively; $\mathrm{CD}_{2} \mathrm{Cl}_{2}: \delta 5.32 \mathrm{ppm}$ and $\delta 53.84 \mathrm{ppm}$, respectively). Elemental analyses were performed by Atlantic Microlabs Inc., Norcross, GA, USA. Highresolution mass spectra were recorded on an Agilent Technologies 6545 Q-TOF LC/MS system. The following abbreviations were used to explain multiplicities: $\mathrm{s}=$ singlet, bs = broad singlet, $\mathrm{d}=$ doublet, $\mathrm{t}=$ triplet, $\mathrm{q}=$ quartet, $\mathrm{p}=$ pentet, $\mathrm{sx}=$ sextet, $\mathrm{h}=$ heptet, $\mathrm{m}=$ multiplet. Melting points were obtained using a Stanford Research Systems EZ-Melt melting point apparatus. Attenuated total reflectance Fourier transform infrared spectra (ATR-FTIR) were obtained using a Thermo Scientific Nicolet iS5 FT-IR spectrometer (iD5 ATR, diamond) referenced to a polystyrene standard and data reported as frequency of absorption $\left(\mathrm{cm}^{-1}\right)$.

\section{2-bromo-2',4',6'-triisopropyl-3-methoxy-1,1'-biphenyl} (S1)

An oven-dried $1000 \mathrm{~mL}$ round-bottom flask equipped with a stir bar and fitted with a rubber septum was evacuated using an inlet needle connected to a Schlenk line. The flask was backfilled with argon (this process was repeated a total of three times). Then, 2-bromo-1,3,5-triisopropylbenzene $(15.5 \mathrm{~mL}, 61.3 \mathrm{mmol})$ and anhydrous THF $(250 \mathrm{~mL})$ were added sequentially and the mixture was cooled to $-78{ }^{\circ} \mathrm{C}$ in a dry ice/acetone bath. $n$-BuLi (1.55 M in hexanes, $41.3 \mathrm{~mL}$, $64.4 \mathrm{mmol}$ ) was added dropwise via syringe over $30 \mathrm{~min}$ and the sides of the flask were rinsed with anhydrous THF (4 $\mathrm{mL}$ ). The resulting bright yellow mixture (solution "A") was stirred at $-78^{\circ} \mathrm{C}$ for $1 \mathrm{~h}$.

A separate oven-dried $1000 \mathrm{~mL}$ round-bottom flask equipped with a stir bar and fitted with a rubber septum was evacuated using an inlet needle connected to a Schlenk line. The flask was backfilled with argon (this process was repeated a total of three times). Then, 3-fluoroanisole (3.50 $\mathrm{mL}, 30.6 \mathrm{mmol})$ and THF $(150 \mathrm{~mL})$ were added sequentially and the mixture was cooled to $-78{ }^{\circ} \mathrm{C}$ in a dry ice/acetone bath. $n$-BuLi (1.63 M in hexanes, $18.2 \mathrm{~mL}, 29.6 \mathrm{mmol}$ ) was added dropwise over $15 \mathrm{~min}$, and the sides of the flask were rinsed with THF $(2 \mathrm{~mL})$. The resulting colorless mixture (solution "B") was stirred at $-78^{\circ} \mathrm{C}$ for $1 \mathrm{~h}$.

At this time, solution $\mathbf{A}$ was cannulated into solution $\mathbf{B}$ over the course of 8 min. Flask A was rinsed with THF (8 mL) and the washings were cannulated into flask $\mathbf{B}$. The combined reaction mixture was then warmed to $-30{ }^{\circ} \mathrm{C}$ in an acetone bath. The reaction was stirred at this temperature for $1 \mathrm{~h}$ (maintained between $-25{ }^{\circ} \mathrm{C}$ and $-35{ }^{\circ} \mathrm{C}$ by addition of dry ice). The mixture was initially cloudy and yellow, but grew homogenous as it warmed.

At this time, bromine ( $4 \mathrm{~mL})$ was carefully added dropwise via syringe over the course of $4 \mathrm{~min}$. The resultant orange solution was removed from the bath and allowed to warm to room temperature for $20 \mathrm{~min}$, at which time saturated aqueous sodium thiosulfate was added $(150 \mathrm{~mL})$. The resulting biphasic mixture was diluted with EtOAc $(150 \mathrm{~mL})$ and water $(100 \mathrm{~mL})$ and transferred to a $1 \mathrm{~L}$ separatory funnel. The light yellow organic phase was sequentially washed with a mixture of saturated aqueous sodium thiosulfate $(150 \mathrm{~mL})$, water $(100 \mathrm{~mL})$, and brine $(150 \mathrm{~mL})$. The organic layer was then dried over $\mathrm{MgSO}_{4}$, filtered, and concentrated in vacuo to give approximately $20 \mathrm{~mL}$ of a thick yellow oil.

The crude material was purified by flash column chromatography (0 to $4 \%$ EtOAc/hexanes) and concentrated to give a yellow semi-solid. This material was further purified by recrystallization by dissolving the compound in hot EtOAc $(5 \mathrm{~mL})$ and layering $\mathrm{MeOH}(10 \mathrm{~mL})$ on top. The biphasic mixture was allowed to cool to room temperature before being moved to the freezer $\left(-40^{\circ} \mathrm{C}\right)$. After $3 \mathrm{~d}$, the resulting crystals were collected via vacuum filtration, rinsed 
sequentially with $\mathrm{MeOH}(5 \mathrm{~mL})$ and hexanes $(5 \mathrm{~mL})$, and then dried under high vacuum to give $\mathbf{S 1}$ as a white solid $(6.29 \mathrm{~g}, 53 \%$ yield $)$.

The characterization data were consistent with previous reports. ${ }^{22}$

${ }^{1} \mathbf{H}$ NMR $\left(500 \mathrm{MHz}, \mathrm{CDCl}_{3}\right): \delta 7.32(\mathrm{t}, J=7.9 \mathrm{~Hz}, 1 \mathrm{H}), 7.07$ (s, 2H), $6.92(\mathrm{~d}, J=8.1 \mathrm{~Hz}, 1 \mathrm{H}), 6.84(\mathrm{~d}, J=7.5 \mathrm{~Hz}, 1 \mathrm{H})$, 3.99 (s, 3H), 2.97 (hept, $J=6.9 \mathrm{~Hz}, 1 \mathrm{H}$ ), 2.47 (hept, $J=6.9$ $\mathrm{Hz}, 2 \mathrm{H}), 1.33$ (d, $J=6.9 \mathrm{~Hz}, 6 \mathrm{H}), 1.19$ (d, $J=6.9 \mathrm{~Hz}, 6 \mathrm{H})$, $1.05(\mathrm{~d}, J=6.8 \mathrm{~Hz}, 6 \mathrm{H}) .{ }^{13} \mathrm{C}$ NMR $\left(126 \mathrm{MHz}, \mathrm{CDCl}_{3}\right): \delta$ $156.01,148.29,145.92,143.54,135.76,127.44,123.78$, $120.69,114.54,109.88,56.25,34.16,30.63,24.80,24.05$, 23.67. IR (neat, $\mathrm{cm}^{-1}$ ): 2957, 2925, 2864, 1562, 1452, 1419, 1359, 1265, 1087, 1018, 783, 776, 719. MP: $117-119^{\circ} \mathrm{C}$.

\section{Di(adamantan-1-yl)(2',4',6'-triisopropyl-3-methoxy- [1,1'-biphenyl]-2-yl)phosphane (S2)}

An oven-dried $350 \mathrm{~mL}$ Schlenk tube equipped with a stir bar was charged with S1 (3.69 g, $9.48 \mathrm{mmol})$ and fitted with a rubber septum. The tube was evacuated using an inlet needle connected to a Schlenk line. The tube was backfilled with argon (this process was repeated a total of three times). Then anhydrous THF $(36 \mathrm{~mL})$ was added and the reaction was cooled to $-78{ }^{\circ} \mathrm{C}$ in a dry ice/acetone bath. $t$-BuLi $(1.70 \mathrm{M}$ in pentane, $20.4 \mathrm{mmol}, 12.0 \mathrm{~mL}$ ) was added dropwise over $11 \mathrm{~min}$, and the resultant bright yellow solution was stirred at $-78^{\circ} \mathrm{C}$ for $1 \mathrm{~h}$.

At this time, the septum was replaced with a Teflon stopcock under a counterflow of argon, and the pentane removed at $78{ }^{\circ} \mathrm{C}$ using an inline vacuum trap cooled with liquid nitrogen. After $30 \mathrm{~min}$ of evacuation, the stopcock was removed and anhydrous $\mathrm{CuCl}$ (1.08 g, $10.9 \mathrm{mmol})$ was added under a counterflow of argon. The tube was quickly fitted with a rubber septum and allowed to warm to room temperature. The solution turned green when $\mathrm{CuCl}$ was added, and darkened to an opaque green-black color as it warmed to rt.

After $30 \mathrm{~min}$, the septum was removed and $\operatorname{di}(1-$ adamantyl)chlorophosphine $(3.54 \mathrm{~g}, 10.5 \mathrm{mmol})$ was quickly added (note: no counterflow of argon was used during this addition to prevent dispersing the fine solid). Anhydrous toluene $(51 \mathrm{~mL})$ was added under counterflow of argon, and then the tube was fitted with a Teflon stopcock, sealed tightly, and placed in an oil bath pre-heated to $140{ }^{\circ} \mathrm{C}$ behind a blast shield.

After $18 \mathrm{~h}$, the reaction was allowed to slowly cool to room temperature, and then diluted with EtOAc $(50 \mathrm{~mL})$ and water $(50 \mathrm{~mL})$ and transferred to a separatory funnel. The organic phase was washed with 2:1 saturated aqueous $\mathrm{NH}_{4} \mathrm{OH}(28$ $30 \% \mathrm{NH}_{3}$ basis)/brine until no blue color was visible in the aqueous phase $(12 \times 40 \mathrm{~mL})$, and then washed once with brine $(1 \times 40 \mathrm{~mL})$. The pale yellow organic phase was then dried over $\mathrm{MgSO}_{4}$ and concentrated in vacuo to give a yellow oil. The crude material was triturated from $\mathrm{MeOH}$ and dried under high vacuum overnight to give $\mathbf{S 2}$ as a white solid (4.52 g, 78\% yield).

${ }^{1} \mathbf{H}$ NMR $\left(600 \mathrm{MHz}, \mathrm{CDCl}_{3}\right): \delta 7.31(\mathrm{t}, J=7.8 \mathrm{~Hz}, 1 \mathrm{H}), 6.99$ (s, 2H), $6.91(\mathrm{~d}, J=8.1 \mathrm{~Hz}, 1 \mathrm{H}), 6.83$ (ddd, $J=7.6,3.7,1.2$ Hz, 1H), 3.89 (s, 3H), 2.95 (hept, $J=7.0 \mathrm{~Hz}, 1 \mathrm{H}$ ), 2.61 (app h, $J=6.8 \mathrm{~Hz}, 2 \mathrm{H}), 1.90(\mathrm{~m}, 18 \mathrm{H}), 1.67(\mathrm{~s}, 12 \mathrm{H}), 1.33(\mathrm{~d}, J=$ $6.9 \mathrm{~Hz}, 6 \mathrm{H}), 1.26(\mathrm{~d}, J=6.7 \mathrm{~Hz}, 6 \mathrm{H}), 0.98(\mathrm{~d}, J=6.6 \mathrm{~Hz}$, $6 \mathrm{H}) .{ }^{13} \mathrm{C}$ NMR $\left(150 \mathrm{MHz}, \mathrm{CDCl}_{3}\right): \delta 161.78,161.76$, $152.16,151.87,147.30,146.08,137.93,137.88,128.73$, $126.08,126.02,123.78,123.41,120.26,108.33,77.16$, 53.97, 42.12, 42.01, 38.95, 38.72, 37.26, 34.05, 30.98, 30.96, 29.43, 29.36, 26.63, 24.22, 23.03. 31P NMR (202 MHz, $\mathrm{CDCl}_{3}$ ): $\delta 35.73$. IR (neat, $\mathrm{cm}^{-1}$ ): 2957, 2907, 2897, 2884, 2848, 1450, 1245, 1009, 874, 794, 778. MP: $220-22{ }^{\circ} \mathrm{C}$. EA: Expected $82.58(\mathrm{C}), 9.74(\mathrm{H})$, found $82.31(\mathrm{C}), 9.60$ (H).

\section{S2-Pd(4-anisyl)Br (1):}

The reaction was set up in a nitrogen-filled glovebox. An oven-dried $100 \mathrm{~mL}$ round-bottom flask equipped with a stir bar was sequentially charged with $\mathbf{S 1}$ (400 mg, $0.66 \mathrm{mmol}$ ), pentane $(30 \mathrm{~mL})$, diethyl ether $(10 \mathrm{~mL})$, and 4-bromoanisole $(126 \mu \mathrm{L}, 0.98 \mathrm{mmol})$. The mixture was allowed to stir until homogenous, and then [(COD) $\left.\mathrm{Pd}\left(\mathrm{CH}_{2} \mathrm{TMS}\right)_{2}\right](282 \mathrm{mg}$, $0.73 \mathrm{mmol}$ ) was added in one portion. The colorless solution quickly turned a bright red color. The flask was sealed with a rubber septum and stirred at room temperature.

After $19 \mathrm{~h}$, the flask was removed from the glovebox. The cloudy red solution was filtered through a fine sintered glass filter under air. The resultant filter cake was rinsed with pentane ( $3 \times 5 \mathrm{~mL}$ ) and dried under high vacuum to give $\mathbf{1}$ as a light red solid (445 $\mathrm{mg}, 75 \%$ yield).

${ }^{1} \mathbf{H}$ NMR $\left(500 \mathrm{MHz}, \mathrm{CDCl}_{3}\right): \delta 8.72(\mathrm{~d}, J=8.7 \mathrm{~Hz}, 1 \mathrm{H}), 7.43$ (t, $J=7.9 \mathrm{~Hz}, 1 \mathrm{H}), 7.00(\mathrm{~d}, J=8.6 \mathrm{~Hz}, 1 \mathrm{H}), 6.99-6.91(2$, $3 \mathrm{H}), 6.82(\mathrm{~d}, J=8.0 \mathrm{~Hz}, 1 \mathrm{H}), 5.87(\mathrm{~s}, 1 \mathrm{H}), 3.94(\mathrm{~s}, 4 \mathrm{H}), 3.80$ (s, 3H), 3.50 (q, $J=7.0 \mathrm{~Hz}, 1 \mathrm{H}), 3.19(\mathrm{~d}, J=35.2 \mathrm{~Hz}, 1 \mathrm{H})$, $3.12-2.98(\mathrm{~m}, 1 \mathrm{H}), 2.29(\mathrm{~d}, J=22.1 \mathrm{~Hz}, 11 \mathrm{H}), 2.03(\mathrm{~d}, J=$ $22.1 \mathrm{~Hz}, 4 \mathrm{H}), 1.93-1.51(\mathrm{~m}, 18 \mathrm{H}), 1.51-1.41(\mathrm{~m}, 1 \mathrm{H})$, $1.37-1.15(\mathrm{~m}, 12 \mathrm{H}), 1.09(\mathrm{~d}, J=6.9 \mathrm{~Hz}, 3 \mathrm{H}), 0.91(\mathrm{t}, J=$ $7.1 \mathrm{~Hz}, 2 \mathrm{H}), 0.69$ (d, J=6.4 Hz, 3H), 0.06 (s, 3H). Observed complexity is due to in situ rearrangement. ${ }^{14}{ }^{13} \mathbf{C ~ N M R ~ ( 1 2 6 ~}$ $\left.\mathrm{MHz}, \mathrm{CDCl}_{3}\right): \delta 158.94,149.27,149.13,134.20,133.99$, $132.20,132.10,130.62,130.57,125.02,124.98,113.63$, 113.46, 110.21, 99.20, 77.28, 77.02, 76.77, 55.31, 54.17, 50.91, 44.98, 44.23, 39.77, 36.68, 36.54, 33.98, 32.48, 31.00, 29.66, 29.59, 28.68, 28.60, 23.19, 22.74, 22.70, 21.82, 21.09, 20.29. ${ }^{31} \mathbf{P}$ NMR $\left(202 \mathrm{MHz}, \mathrm{CDCl}_{3}\right): \delta 85.28$. IR (neat, $\mathrm{cm}^{-}$ 1): 2903, 2846, 1456, 1265, 1254, 1230, 1173, 1040, 1000, 806, 792. HRMS (ESI): calc'd for $\left(\left[\mathrm{C}_{49} \mathrm{H}_{66} \mathrm{BrO}_{3} \mathrm{PPd}\right]-\mathrm{Br}\right)^{+}$: 823.3835; found: 823.3841

\section{Initial Synthesis of Hexasubstituted Arene 3:}

An oven-dried $25 \mathrm{~mL}$ round-bottom flask equipped with a stir bar was charged with 1 (391 mg, $0.43 \mathrm{mmol}$ ) and fitted with a rubber septum. The flask was evacuated using an inlet 
needle connected to a Schlenk line. The flask was backfilled with argon (this process was repeated a total of three times.) Then, anhydrous THF $(10 \mathrm{~mL})$ was added to give a deep red solution. 4-Bromoanisole $(81 \mu \mathrm{L}, 0.65 \mathrm{mmol})$ and DBU (71 $\mu \mathrm{L}, 0.48 \mathrm{mmol}$ ) were added sequentially via syringe, and the reaction was stirred at room temperature under argon. The color lightened to yellow, and formation of a precipitate was observed.

After $17 \mathrm{~h}$, the reaction was opened to the air and filtered over a pad of Celite (rinsing with THF). The resultant solution was concentrated in vacuo to give a brown foam, which was triturated from ether and filtered to give a yellow solid. The solid was suspended in THF $(10 \mathrm{~mL})$ and $\mathrm{CH}_{2} \mathrm{Cl}_{2}$ $(2 \mathrm{~mL})$, and the resultant solution was sparged with argon for $15 \mathrm{~min}$. Ethylene diamine (95 uL, $1.5 \mathrm{mmol})$ was added via syringe, and the reaction was stirred under argon at room temperature.

After $22 \mathrm{~h}$, the reaction was diluted with EtOAc $(10 \mathrm{~mL})$ and a mixture of $2: 1$ saturated aqueous $\mathrm{NH}_{4} \mathrm{OH}\left(28-30 \% \mathrm{NH}_{3}\right.$ basis)/brine $(10 \mathrm{~mL})$ and transferred to a separatory funnel. The organic phase was washed with 2:1 saturated aqueous $\mathrm{NH}_{4} \mathrm{OH}\left(28-30 \% \quad \mathrm{NH}_{3}\right.$ basis $) /$ brine $(10 \mathrm{~mL})$ and then washed with brine $(10 \mathrm{~mL})$. The organic layer was then dried over $\mathrm{MgSO}_{4}$ and concentrated in vacuo to give a brown oil. The crude material was triturated from $\mathrm{MeOH}$ to give a tan solid $(189 \mathrm{mg}) .{ }^{31} \mathrm{P} \mathrm{NMR}$ analysis $\left(121 \mathrm{MHz}, \mathrm{CDCl}_{3}\right)$ revealed this to be a mixture of $\mathbf{3}(\delta 36.86)$ and $\mathbf{2}(\delta 36.07)$ in a 1.00:0.79 ratio (product identities were confirmed via LCMS).

\section{Di(adamant-1-yl)(2',4',6'-triisopropyl-3,4''-dimethoxy- 5'-(4-methoxyphenyl)-[1,1':3',1'-terphenyl]-2- yl)phosphane (3):}

A flame-dried $100 \mathrm{~mL}$ round-bottom flask equipped with a stir bar was charged with 1 (500 mg, $0.55 \mathrm{mmol})$ and fitted with a rubber septum. The flask was evacuated using an inlet needle connected to a Schlenk line. The flask was backfilled with argon (this process was repeated a total of three times). Then anhydrous THF ( $40 \mathrm{~mL}$ ) was added to give a deep red solution. Then, 4-bromoanisole $(243 \mu \mathrm{L}, 1.94 \mathrm{mmol})$ and DBU (174 $\mu \mathrm{L}, 1.16 \mathrm{mmol})$ were added sequentially via syringe and the reaction was placed in an oil bath preheated to $40{ }^{\circ} \mathrm{C}$. The reaction became a deep yellow color after 15 $\min$.

After stirring for $6 \mathrm{~d}$ at $40{ }^{\circ} \mathrm{C}$, ethylene diamine $(185 \mu \mathrm{L}$, $2.76 \mathrm{mmol}$ ) was added via syringe, and the reaction was stirred at room temperature for $15 \mathrm{~h}$. Then the reaction mixture was diluted with EtOAc $(30 \mathrm{~mL})$ and transferred to a separatory funnel. The organic phase was washed with 2:1 saturated aqueous $\mathrm{NH}_{4} \mathrm{OH}\left(28-30 \% \mathrm{NH}_{3}\right.$ basis)/brine $(2 \mathrm{x}$ $20 \mathrm{~mL})$ and brine $(1 \times 20 \mathrm{~mL})$. The organic layer was then dried over $\mathrm{MgSO}_{4}$ and concentrated in vacuo to give a brown oil. The crude material was triturated from $\mathrm{MeOH}$ to give a tan solid (366 mg). ${ }^{31} \mathrm{P}$ NMR analysis showed this to be a mixture of $\mathbf{3}$ and $\mathbf{2}$ in a $96: 4$ ratio.
The tan solid was dissolved in $\mathrm{CH}_{2} \mathrm{Cl}_{2}(2 \mathrm{~mL})$ with gentle heating and $\mathrm{MeOH}(2 \mathrm{~mL})$ was layered on top. The biphasic mixture was allowed to cool slowly to room temperature, and then cooled in the freezer $\left(-40^{\circ} \mathrm{C}\right)$ for $4 \mathrm{~h}$. The resultant crystals were filtered, rinsed with methanol, and dried under high vacuum to give 3 as an off-white solid (257 mg, 56\% yield).

The mother liquor from the crystals was left in the freezer for an additional $6 \mathrm{~d}$, and then filtered, rinsed with $\mathrm{MeOH}$, and dried under high vacuum to give $\mathbf{3}$ as an off-white solid (56 mg, 69\% combined yield).

${ }^{1} \mathrm{H}$ NMR (400 MHz, $\left.\mathrm{CD}_{2} \mathrm{Cl}_{2}\right): \delta 7.41-7.20(\mathrm{~m}, 4 \mathrm{H}), 7.20-$ $7.13(\mathrm{~m}, 1 \mathrm{H}), 6.96-6.81(\mathrm{~m}, 6 \mathrm{H}), 3.89(\mathrm{~s}, 3 \mathrm{H}), 3.86(\mathrm{~s}, 6 \mathrm{H})$, 2.92 (hept, $J=7.3 \mathrm{~Hz}, 1 \mathrm{H}), 2.78(\mathrm{~m}, J=14.2,7.0 \mathrm{~Hz}, 2 \mathrm{H})$, $2.06-1.84(\mathrm{~m}, 18 \mathrm{H}), 1.78-1.63(\mathrm{~m}, 12 \mathrm{H}), 0.91(\mathrm{~d}, J=6.9$ $\mathrm{Hz}, 6 \mathrm{H}), 0.81(\mathrm{~d}, J=7.3 \mathrm{~Hz}, 3 \mathrm{H}), 0.59(\mathrm{~d}, J=7.3 \mathrm{~Hz}, 3 \mathrm{H})$, $0.45(\mathrm{~m}, 6 \mathrm{H}) .{ }^{13} \mathrm{C}$ NMR $\left(126 \mathrm{MHz}, \mathrm{CDCl}_{3}\right) \delta 161.90$, $158.48,158.01,154.66,154.37,144.77,143.89,142.75$, $140.06,140.02$, 138.08, 138.03, 135.83, 135.56, 135.54, $133.84,133.42$, 133.27, 131.13, 128.23, 125.61, 125.56, 112.46, 112.08, 111.02, 110.85, 107.80, 55.17, 53.83, 41.93, $41.81,38.68,38.45,37.12,33.01,32.76,30.54,29.28,29.21$, 25.03, 24.95, 23.80, 23.55, 22.81. ${ }^{31} \mathbf{P}$ NMR (203 MHz, $\mathrm{CD}_{2} \mathrm{Cl}_{2}$ ): $\delta$ 36.82. IR (neat, $\mathrm{cm}^{-1}$ ): 2991, 2901, 2845, 1506, 1455, 1281, 1236, 1173, 1041, 1029, 802, 792, 737. MP: 214-215 ${ }^{\circ} \mathrm{C}$. HRMS (ESI): calc'd for $\left(\left[\mathrm{C}_{56} \mathrm{H}_{71} \mathrm{O}_{3} \mathrm{P}_{3}\right]+\mathrm{H}\right)^{+}$: 823.5225; found: 823.5216

\section{3-Pd(4-benzotrifluoride)Br (4):}

An oven-dried $100 \mathrm{~mL}$ round-bottom flask equipped with a stir bar was charged with $\mathbf{3}$ (100 mg, $0.12 \mathrm{mmol})$ and fitted with a rubber septum. The flask was evacuated using an inlet needle connected to a Schlenk line. The flask was backfilled with argon (this process was repeated a total of three times). Anhydrous pentane $(30 \mathrm{~mL})$ and diethyl ether $(20 \mathrm{~mL})$ were added to give a clear solution, and 4-bromobenzotrifluoride ( $26 \mu \mathrm{L}, 0.19 \mathrm{mmol})$ was added via syringe. The septum was then removed and [(COD) $\left.\mathrm{Pd}\left(\mathrm{CH}_{2} \mathrm{TMS}\right)_{2}\right](52 \mathrm{mg}, 0.13$ mmol) was quickly added under air. The septum was replaced and the reaction was stirred at room temperature under argon. The mixture slowly turned a cloudy green color.

After $15 \mathrm{~h}$, the mixture was filtered through a medium sintered glass filter under air. The resultant filter cake was rinsed with pentane $(2 \times 2 \mathrm{~mL})$ and dried under high vacuum to give 4 as a yellow-green solid (37 mg, 26\% yield).

${ }^{1} \mathbf{H}$ NMR $\left(500 \mathrm{MHz}, \mathrm{CDCl}_{3}\right): \delta 7.89(\mathrm{dd}, J=30.9,8.4 \mathrm{~Hz}$, $2 \mathrm{H}), 7.47(\mathrm{~d}, J=8.2 \mathrm{~Hz}, 2 \mathrm{H}), 7.37(\mathrm{t}, J=7.9 \mathrm{~Hz}, 1 \mathrm{H}), 7.26$ $(\mathrm{m}, 1 \mathrm{H}), 7.14(\mathrm{~d}, J=8.3 \mathrm{~Hz}, 3 \mathrm{H}), 6.84(\mathrm{dt}, J=24.0,8.9 \mathrm{~Hz}$, $5 \mathrm{H}), 6.50(\mathrm{dd}, J=7.7,2.7 \mathrm{~Hz}, 1 \mathrm{H}), 3.92(\mathrm{~s}, 3 \mathrm{H}), 3.85(\mathrm{~s}, 6 \mathrm{H})$, $3.50(\mathrm{q}, J=7.0 \mathrm{~Hz}, 1 \mathrm{H}), 3.07-2.76(\mathrm{~m}, 3 \mathrm{H}), 2.44-2.03$ (m, 12H), $2.03-1.51(\mathrm{~m}, 19 \mathrm{H}), 1.40-1.15(\mathrm{~m}, 2 \mathrm{H}), 1.08-$ $0.87(\mathrm{~m}, 6 \mathrm{H}), 0.78(\operatorname{app~q}, J=8.2,7.1 \mathrm{~Hz}, 9 \mathrm{H}), 0.66(\mathrm{~d}, J=$ $7.2 \mathrm{~Hz}, 3 \mathrm{H}) .{ }^{13} \mathbf{C ~ N M R}\left(126 \mathrm{MHz}, \mathrm{CDCl}_{3}\right) \delta 160.71,158.88$, 
$158.37,157.20,151.74,151.60,150.39,141.22,140.83$, $140.15,139.66,139.64,136.39,133.88,133.77,133.53$, $131.82,131.58,131.09,129.33,129.25,127.06,123.75$, 123.64, 121.76, 121.73, 121.64, 121.62, 121.47, 112.27, 111.91, 110.76, 110.67, 108.73, 55.15, 53.75, 47.58, 47.49, $47.43,47.36,41.45,41.22,36.27,33.71,33.30,31.33,29.49$, 29.41, 25.44, 25.14, 24.35, 23.72, 23.37, 23.14. ${ }^{31} \mathbf{P}$ NMR $\left(202 \mathrm{MHz}, \mathrm{CDCl}_{3}\right): \delta 67.30 .{ }^{19} \mathbf{F}$ NMR $\left(470 \mathrm{MHz}, \mathrm{CDCl}_{3}\right)$ : $\delta$-61.71. IR (neat, $\mathrm{cm}^{-1}$ ): 2907, 1585, 1455, 1326, 1238, 1099, 1067, 1035, 1005, 816. HRMS (ESI): calc'd for $\left(\left[\mathrm{C}_{63} \mathrm{H}_{75} \mathrm{BrF}_{3} \mathrm{O}_{3} \mathrm{PPd}\right]-\mathrm{Br}\right)^{+}$: 1073.4441 ; found: 1073.4446

\section{C-N Coupling using 4 as precatalyst:}

Protocol adapted from the literature. ${ }^{17}$

An oven-dried "small" reaction tube (vide supra) equipped with a stir bar was charged with 4 (3.2 $\mathrm{mg}, 0.0028 \mathrm{mmol})$. The reaction tube was sealed with a screw cap containing a Teflon septum. The tube was evacuated using an inlet needle connected to a Schlenk line. The tube was backfilled with argon (this process was repeated a total of three times). Then 3-bromoanisole ( $32 \mu \mathrm{L}, 0.25 \mathrm{mmol}), n$-butyl amine $(30 \mu \mathrm{L}$, $0.30 \mathrm{mmol})$, DBU $(75 \mu \mathrm{L}, 0.50 \mathrm{mmol})$, and MTBE $(120 \mu \mathrm{L})$ were added sequentially via syringe. The mixture was a cloudy green color. The septum was exchanged with a new one that had not been punctured, and the tube was added to an oil bath preheated to $60{ }^{\circ} \mathrm{C}$. After $5 \mathrm{~min}$, the reaction mixture turned a light green color and became homogenous.

After $17 \mathrm{~h}$, the tube was removed from the oil bath and allowed to cool to room temperature. The reaction mixture had become a light brown color. Dodecane $(12.5 \mu \mathrm{L})$ was added via syringe, and the crude mixture was diluted with $\mathrm{CH}_{2} \mathrm{Cl}_{2}(0.5 \mathrm{~mL})$.

An aliquot was diluted with EtOAc and analyzed by GC. By comparison to a calibration curve, the product was shown to have formed in $1.6 \%$ yield.

5'-(4-butylphenyl)-2"'-(di(adamantan-1yl)phosphaneyl)-2',4',6'-triisopropyl-3''-methoxy- $N, N$ dimethyl-[1,1':3',1'-terphenyl]-4-amine (8):

An oven-dried $100 \mathrm{~mL}$ round-bottom flask equipped with a stir bar was brought into a nitrogen-filled glovebox and charged with S2 (400 mg, $0.655 \mathrm{mmol}$ ) and subsequently dissolved in a mixture of anhydrous $\mathrm{Et}_{2} \mathrm{O}(10 \mathrm{~mL})$ and anhydrous pentane $(52 \mathrm{~mL})$. Then, 1-bromo-4- $n$ butylbenzene (209 $\mathrm{mg}, 0.982 \mathrm{mmol})$ was added via microliter pipette, followed by $\left[(\mathrm{COD}) \mathrm{Pd}\left(\mathrm{CH}_{2} \mathrm{TMS}\right)\right]_{2}(280$ $\mathrm{mg}, 0.720 \mathrm{mmol})$. The flask was sealed with a rubber septum, removed from the glovebox, and the red heterogeneous solution allowed to stir at rt for $24 \mathrm{~h}$. At this time, the resulting yellow precipitate was collected using a sintered glass funnel. The filter cake was washed with pentane $(5 \times 3 \mathrm{~mL})$ to afford the oxidative addition complex, a portion of which was used directly in the next step without further purification (424 mg, 70\%).
An oven-dried $25 \mathrm{~mL}$ "medium" reaction tube (vide supra) equipped with a stir bar was charged with the oxidative complex prepared above (106 $\mathrm{mg}, 0.114 \mathrm{mmol}$ ) and 4bromo- $N, N$-dimethylaniline $(57.0 \mathrm{mg}, 0.285 \mathrm{mmol})$. The reaction tube was sealed with a screw cap containing a septum (both "medium" size) and evacuated using an inlet needle connected to a Schlenk line. The tube was backfilled with argon (this process was repeated a total of three times.) Anhydrous THF $(7 \mathrm{~mL})$ was added and the reaction mixture was stirred at rt. Then, DBU $(40 \mu \mathrm{L}, 0.27 \mathrm{mmol})$ was added and the septum was exchanged for one that had not been punctured under a counterflow of argon. The reaction mixture was then allowed to stir at rt.

After $3 \mathrm{~d}$, ethylene diamine $(100 \mu \mathrm{L}, 1.50 \mathrm{mmol})$ was added via syringe and the reaction mixture was allowed to stir at $\mathrm{rt}$ for an additional $24 \mathrm{~h}$. Then, the tube was opened to the air and transferred to a separatory funnel containing EtOAc (50 $\mathrm{mL})$. The organic phase was washed with $2: 1$ saturated aqueous $\mathrm{NH}_{4} \mathrm{OH}\left(28-30 \% \mathrm{NH}_{3}\right.$ basis $) /$ brine $(3 \times 50 \mathrm{~mL})$, followed by brine $(1 \times 50 \mathrm{~mL})$. The organic layer was dried over $\mathrm{MgSO}_{4}$ and concentrated in vacuo. The crude residue was purified via flash column chromatography (Biotage KPSIL $25 \mathrm{~g}$ column, eluting $0 \%$ to $100 \% \mathrm{CH}_{2} \mathrm{Cl}_{2} / \mathrm{EtOAc}$ ), followed by crystallization from $\mathrm{CH}_{2} \mathrm{Cl}_{2} / \mathrm{MeOH}$ to afford 8 as a white solid (29.4 mg, 30\%). Contains approximately $5 \%$ (as determined by LC/MS) of $\mathbf{S 2}$.

${ }^{1} \mathbf{H}$ NMR (600 MHz, $\left.\mathrm{CDCl}_{3}\right): \delta 7.25-7.22(\mathrm{~m}, 1 \mathrm{H}), 7.18(\mathrm{~d}$, $J=8.2 \mathrm{~Hz}, 1 \mathrm{H}), 7.16-7.02(\mathrm{~m}, 5 \mathrm{H}), 6.97(\mathrm{dd}, J=7.7,3.5$ $\mathrm{Hz}, 1 \mathrm{H}), 6.81(\mathrm{~d}, J=8.1 \mathrm{~Hz}, 1 \mathrm{H}), 6.69(\mathrm{~d}, J=8.3 \mathrm{~Hz}, 1 \mathrm{H})$, $6.64(\mathrm{~m}, 1 \mathrm{H}), 3.84(\mathrm{~s}, 3 \mathrm{H}), 2.96(\mathrm{~d}, J=5.3 \mathrm{~Hz}, 6 \mathrm{H}), 2.84(\mathrm{~m}$, $1 \mathrm{H}), 2.67(\mathrm{~m}, 2 \mathrm{H}), 2.63(\mathrm{t}, J=7.9 \mathrm{~Hz}, 2 \mathrm{H}), 1.87(\mathrm{~m}, 18 \mathrm{H})$, $1.64(\mathrm{~m}, 14 \mathrm{H}), 1.37(\mathrm{~h}, J=6.9 \mathrm{~Hz}, 2 \mathrm{H}), 0.92(\mathrm{~m}, 9 \mathrm{H}), 0.75$ (dd, $J=21.5,7.2 \mathrm{~Hz}, 3 \mathrm{H}), 0.57(\mathrm{dd}, J=32.3,7.3 \mathrm{~Hz}, 3 \mathrm{H})$, $0.43(\mathrm{dd}, J=15.3,7.1 \mathrm{~Hz}, 3 \mathrm{H}), 0.34(\mathrm{dd}, J=13.1,6.8 \mathrm{~Hz}$, $3 \mathrm{H}) .{ }^{13} \mathbf{C}$ NMR $\left(151 \mathrm{MHz}, \mathrm{CDCl}_{3}\right) \delta 161.98,155.01,154.77$, $149.54,149.06,144.89,144.19,143.30,143.05,141.19$, $140.70,140.60,140.04,138.81,138.59,138.50,135.62$, $134.92,133.73,133.06,132.35,131.63,131.03,130.33$, $129.59,128.29,126.90,126.85,125.94,125.88,125.83$, $125.83,125.60,125.57,122.95,122.63,111.49,111.21$, $110.11,109.96,107.83,77.16,53.95,42.05,41.95,40.88$, $38.80,38.60,37.64,37.28,37.01,35.58,33.99,33.85,33.23$, $33.12,32.98,32.86,30.83,30.61,29.43,29.37,25.15,25.08$, 24.00, 23.77, 22.97, 22.62, 22.51, 14.18 (complex spectrum, in part due to C-P coupling). ${ }^{31} \mathbf{P}$ NMR $\left(203 \mathrm{MHz}, \mathrm{CDCl}_{3}\right)$ : $\delta$ 36.89. IR (neat, $\mathrm{cm}^{-1}$ ): 2901, 2846, 1613, 1516, 1456, 1350, 1264, 1028, 822, 797. HRMS (ESI) m/z calc'd for $\left(\left[\mathrm{C}_{60} \mathrm{H}_{80} \mathrm{NOP}\right]+\mathrm{H}\right)^{+}$: 862.6056; found: 862.6051. MP: 239 $241^{\circ} \mathrm{C}$.

\section{Di-tert-butyl(4'"-butyl-2',4',6'-triisopropyl-3,6- dimethoxy-5'-(4-methoxyphenyl)-[1,1':3',1''-terphenyl]- 2-yl)phosphane (10):}

An oven-dried $100 \mathrm{~mL}$ round-bottom flask equipped with a stir bar was brought into a nitrogen-filled glovebox and charged with $t$-BuBrettPhos $(400 \mathrm{mg}, 0.655 \mathrm{mmol})$ and 
subsequently dissolved in anhydrous pentane $(20 \mathrm{~mL})$. Then, 1-bromo-4- $n$-butylbenzene (264 mg, $1.24 \mathrm{mmol}$ ) was added via microliter pipette, followed by $\left[(\mathrm{COD}) \mathrm{Pd}\left(\mathrm{CH}_{2} \mathrm{TMS}\right)\right]_{2}$ (353 $\mathrm{mg}, 0.908 \mathrm{mmol}$ ). The flask was sealed with a rubber septum, removed from the glovebox, and the red heterogeneous solution allowed to stir at $\mathrm{rt}$ for $25 \mathrm{~h}$. At this time, the resulting yellow-gold precipitate was collected using a sintered glass funnel. The filter cake was washed with pentane $(2 \times 5 \mathrm{~mL})$ to afford the oxidative addition complex, a portion of which was used directly in the next step without further purification (467 mg, 70\%).

An oven-dried $100 \mathrm{~mL}$ round-bottom flask equipped with a magnetic stir bar was charged with the oxidative complex prepared above $(400 \mathrm{mg}, 0.497 \mathrm{mmol})$ and sealed with a rubber septum. The flask was evacuated using an inlet needle connected to a Schlenk line. The flask was backfilled with argon (this process was repeated a total of three times). The solid was dissolved in anhydrous THF $(30 \mathrm{~mL})$ to give a deep red solution. Then, 4-bromoanisole $(219 \mu \mathrm{L}, 1.74$ mmol) and DBU (156 $\mu \mathrm{L}, 1.04 \mathrm{mmol})$ were added sequentially via syringe. The argon line was removed and the reaction was left to stir at room temperature. The reaction became a cloudy yellow color after $5 \mathrm{~min}$.

After $6 \mathrm{~d}$, ethylene diamine $(166 \mu \mathrm{L}, 2.49 \mathrm{mmol})$ was added via syringe and the reaction mixture was allowed to stir at $\mathrm{rt}$ for an additional $24 \mathrm{~h}$. The resultant cloudy white solution was opened to the air, diluted with EtOAc $(20 \mathrm{~mL})$, and transferred to a separatory funnel. The organic phase was washed with 2:1 saturated aqueous $\mathrm{NH}_{4} \mathrm{OH}\left(28-30 \% \mathrm{NH}_{3}\right.$ basis $)$ /brine $(2 \times 20 \mathrm{~mL})$ and brine $(1 \times 20 \mathrm{~mL})$. The organic phase was then dried over $\mathrm{MgSO}_{4}$ and concentrated in vacuo. The crude residue was dissolved in 1:1 EtOAc/ $/ \mathrm{CH}_{2} \mathrm{Cl}_{2}$ and filtered through a pad of silica and then concentrated in vacuo. The crude material was then purified via flash column chromatography (Biotage KP-SIL $50 \mathrm{~g}$ column, eluting $5 \%$ to $25 \%$ EtOAc/99:1 hexanes/Et $3 \mathrm{~N}$ ), followed by crystallization from $\mathrm{CH}_{2} \mathrm{Cl}_{2} / \mathrm{MeOH}$. Recovery of two crops of material yielded approximately $210 \mathrm{mg}$ of 10, contaminated with another phosphine (presumably monoarylated $t$-BuBrettPhos) in a 92:8 ratio. This material was again recrystallized from EtOAc/MeOH to afford $\mathbf{1 0}$ as a white solid $(89.9 \mathrm{mg}, 25 \%)$. Contains approximately $6 \%$ of monoarylated $t$-BuBrettPhos (as determined by LC/MS and ${ }^{31}$ P NMR).

${ }^{1} \mathbf{H}$ NMR $\left(500 \mathrm{MHz}, \mathrm{CDCl}_{3}\right) \delta 7.35-7.30(\mathrm{~m}, 1 \mathrm{H}), 7.26-$ $7.01(\mathrm{~m}, 5 \mathrm{H}), 6.91-6.73(\mathrm{~m}, 4 \mathrm{H}), 3.86(\mathrm{~s}, 3 \mathrm{H}), 3.77(\mathrm{~s}, 3 \mathrm{H})$, $3.65(\mathrm{~s}, 3 \mathrm{H}), 2.91-2.82(\mathrm{~m}, 1 \mathrm{H}), 2.75-2.60(\mathrm{~m}, 4 \mathrm{H}), 1.71$ $-1.61(\mathrm{~m}, 2 \mathrm{H}), 1.44-1.33(\mathrm{~m}, 2 \mathrm{H}), 1.16(\mathrm{~s}, 9 \mathrm{H}), 1.14(\mathrm{~s}$, $9 \mathrm{H}), 0.96(\mathrm{t}, J=7.3 \mathrm{~Hz}, 3 \mathrm{H}), 0.91(\mathrm{~d}, J=7.0 \mathrm{~Hz}, 6 \mathrm{H}), 0.76$ $(\mathrm{t}, J=6.1 \mathrm{~Hz}, 3 \mathrm{H}), 0.62-0.52(\mathrm{~m}, 3 \mathrm{H}), 0.49-0.42(\mathrm{~m}, 3 \mathrm{H})$, $0.42-0.37(\mathrm{~m}, 3 \mathrm{H}) .{ }^{13} \mathbf{C} \mathbf{~ N M R}\left(126 \mathrm{MHz}, \mathrm{CDCl}_{3}\right) \delta 158.38$, $157.92,156.15,152.51,152.42,144.36,144.08,143.16$, $143.05,143.01,142.75,140.99,140.45,140.43,138.44$, $138.37,137.92,137.84,135.76,135.68,135.48,134.64$, $134.23,133.66,133.40,133.18,132.26,131.50,130.79$,
$130.45,126.85,126.69,126.63,126.59,126.47,125.39$, $118.54,112.24,111.93,110.87,110.71,110.30,107.55$, 55.14, 53.82, 35.44, 33.84, 33.71, 33.67, 33.43, 33.17, 32.95, $31.85,31.72,30.55,24.40,24.17,23.93,23.70,22.73,22.62$, 22.44, 22.35, 14.04. ${ }^{31} \mathbf{P}$ NMR (202 MHz, $\left.\mathrm{CDCl}_{3}\right): \delta 36.86$. IR (neat, $\mathrm{cm}^{-1}$ ): 2926, 2871, 1456, 1423, 1248, 1144, 1039, 1025, 834, 795, 783, 574. HRMS (ESI) m/z calc'd for $\left(\left[\mathrm{C}_{48} \mathrm{H}_{67} \mathrm{O}_{3} \mathrm{P}\right]+\mathrm{H}\right)^{+}:$723.4912; found 723.4903. MP: 203$204{ }^{\circ} \mathrm{C}$.

\section{Di(adamantan-1-yl)(2',4',6'-triisopropyl-3,4'"- dimethoxy-[1,1':3',1"'-terphenyl]-2-yl)phosphane (2):}

An oven-dried $100 \mathrm{~mL}$ round-bottom flask equipped with a stir bar was charged with 1 (402 mg, $0.45 \mathrm{mmol}$ ) and sealed with a rubber septum. The flask was evacuated using an inlet needle connected to a Schlenk line. The flask was backfilled with argon (this process was repeated a total of three times.) Anhydrous THF (30 mL) was added to give a deep red solution. Then, 2-bromothiophene $(65 \mu \mathrm{L}, 0.67 \mathrm{mmol})$ and DBU $(75 \mu \mathrm{L}, 0.50 \mathrm{mmol})$ were added sequentially via syringe. The argon line was removed, and the reaction was stirred at rt. The reaction lightened to a yellow-orange color over the next few hours.

After $23 \mathrm{~h}$, ethylene diamine $(150 \mu \mathrm{L}, 2.22 \mathrm{mmol})$ was added via syringe, and the reaction was stirred at room temperature for $18 \mathrm{~h}$. Then the reaction mixture was diluted with EtOAc $(30 \mathrm{~mL})$ and transferred to a separatory funnel. The organic phase was washed with $2: 1$ saturated aqueous $\mathrm{NH}_{4} \mathrm{OH}(28-$ $30 \% \mathrm{NH}_{3}$ basis)/brine $(2 \times 30 \mathrm{~mL})$ and brine $(1 \times 30 \mathrm{~mL})$. Then, the organic phase was dried over $\mathrm{MgSO}_{4}$, and concentrated in vacuo to give a brown oil. The crude mixture was triturated from $\mathrm{MeOH}$ to give $\mathbf{2}$ as a tan solid (268 mg, $84 \%$ yield).

${ }^{1} \mathbf{H}$ NMR (500 MHz, $\mathrm{CDCl}_{3}$ ): $\delta 7.30$ (app t, $\left.J=7.6 \mathrm{~Hz}, 1 \mathrm{H}\right)$, 7.18 (app t, $J=7.6 \mathrm{~Hz}, 2 \mathrm{H}), 7.10(\mathrm{~s}, 1 \mathrm{H}), 6.89(\mathrm{~m}, 4 \mathrm{H}), 3.88$ $(\mathrm{s}, 6 \mathrm{H}), 2.82(\mathrm{~m}, 1 \mathrm{H}), 2.53(\mathrm{~m}, 2 \mathrm{H}), 1.91(\mathrm{~m}, 18 \mathrm{H}), 1.65(\mathrm{~m}$, $12 \mathrm{H}), 1.25(\mathrm{~d}, J=6.7 \mathrm{~Hz}, 3 \mathrm{H}), 1.12(\mathrm{~d}, J=6.8 \mathrm{~Hz}, 3 \mathrm{H}), 1.06$ $(\mathrm{d}, J=6.8 \mathrm{~Hz}, 3 \mathrm{H}), 1.00(\mathrm{~d}, J=6.5 \mathrm{~Hz}, 3 \mathrm{H}), 0.91(\mathrm{~d}, J=6.9$ $\mathrm{Hz}, 3 \mathrm{H}), 0.54(\mathrm{~d}, J=7.1 \mathrm{~Hz}, 3 \mathrm{H}) \cdot{ }^{13} \mathbf{C}$ NMR $(125 \mathrm{MHz}$, $\left.\mathrm{CDCl}_{3}\right): \delta 161.73,158.05,153.25,152.95,147.05,145.73$, $142.56,138.74,136.44,134.41,133.18,131.59,128.43$, $125.90,123.37,122.99,118.73,112.40,112.06,108.01$, $55.17,53.82,42.03,41.92,41.80,38.96,38.73,38.65,38.42$, $37.14,37.11,32.52,31.12,29.31,29.28,29.24,29.21,26.63$, 24.73, 24.43, 24.35, 23.83, 22.93. ${ }^{31} \mathbf{P}$ NMR (203 MHz, $\mathrm{CDCl}_{3}$ ): $\delta$ 36.24. IR (neat, $\mathrm{cm}^{-1}$ ): 2957, 2899, 2847, 1558, 1512, 1456, 1280, 1244, 1174, 1089, 1034, 839, 790. MP: 155-200 ${ }^{\circ} \mathrm{C}$ (slow decomposition) HRMS (ESI): calc'd for $\left(\left[\mathrm{C}_{49} \mathrm{H}_{65} \mathrm{O}_{2} \mathrm{P}\right]+\mathrm{H}\right)^{+}:$717.4806; found: 717.4805

\section{ASSOCIATED CONTENT:}

The supporting information is available free of charge on the ACS Publications website. 
Copies of ${ }^{1} \mathrm{H},{ }^{13} \mathrm{C},{ }^{19} \mathrm{~F}$, and ${ }^{31} \mathrm{P}$ NMR spectra, crystallographic details, and additional substrates not mentioned in the text (PDF)

Solid-state structure of $\mathbf{3}$ (CIF)

\section{AUTHOR INFORMATION:}

\section{Corresponding Author:}

E-mail: sbuchwal@mit.edu

\section{Notes:}

The authors declare the following competing financial interest(s): MIT has patents on some of the ligands and precatalysts used in this work, from which S.L.B. and former coworkers receive royalty payments.

\section{ACKNOWLEDGEMENTS:}

This work was supported by the National Institutes of Health under Award Number R35GM122483. The content is solely the responsibility of the authors and does not necessarily represent the official views of the NIH. We thank Dr. Charlene Tsay (MIT) for solving the X-ray structure of 3. We also thank Dr. Scott McCann, Dr. Andy Thomas, Richard Liu, and Dr. Christine Nguyen for assistance with the preparation of this manuscript. The X-ray diffractometer was purchased with the help of funding from the National Science Foundation (Grant No. CHE 0946721). C.C.W. acknowledges Jacob Rodriguez for assistance with mass spectrometry, Richard Liu for helpful discussions, and MIT for support through the Paul E. Gray (1954) UROP Fund.

\section{REFERENCES:}

(1) Arnett, E. M.; Bollinger, J. M.; Hopff, H.; Chimia ; Hopff, H.; Gati, A.; Gribble, G. W.; Leese, R. M.; Evans, B. E.; Nicholas, K. M.; Pettit, R.; et al. Static and Dynamic Stereochemistry of Hexaisopropylbenzene: A Gear-Meshed Hydrocarbon of Exceptional Rigidity. J. Am. Chem. Soc. 1986, 108, 4999.

Baldridge, K. K.; Siegel, J. S. Bond Alternation in Triannelated Benzenes: Dissection of Cyclic .Pi. from Mills-Nixon Effects. J. Am. Chem. Soc. 1992, 114, 9583-9587.

Singh, M. D.; Siegel, J.; Biali, S. E.; Mislow, K. Conformational Cycloenantiomerism in 1,2-Bis(1Bromoethyl)-3,4,5,6-Tetraisopropylbenzene. $J$. Am. Chem. Soc. 1987, 109, 3397-3402.

(4) Weissensteiner, W.; Gutierrez, A.; Radcliffe, M. D.; Siegel, J.; Singh, M. D.; Tuohey, P. J.; Mislow, K. Conformations and Mobility in Heterosubstituted Hexaalkylbenzenes. J. Org. Chem. 1985, 50, 5822-5827.
Hennrich, G.; Anslyn, E. V. 1,3,5-2,4,6Functionalized, Facially Segregated BenzenesExploitation of Sterically Predisposed Systems in Supramolecular Chemistry. Chem. - A Eur. J. 2002, 8, 2218.

Tupchiangmai, W.; Choksakulporn, S.; Tewtrakul, S.; Pianwanit, S.; Sritana-anant, Y. Use of a Hexasubstituted Benzene Scaffold in the Development of Multivalent HIV-1 Integrase Inhibitors. Chem. Pharm. Bull. 2014, 62, 754-763.

Chabre, Y. M.; Brisebois, P. P.; Abbassi, L.; Kerr, S. C.; Fahy, J. V.; Marcotte, I.; Roy, R. Hexaphenylbenzene as a Rigid Template for the Straightforward Syntheses of "Star-Shaped" Glycodendrimers. J. Org. Chem. 2011, 76 (2), 724-727.

(8) Jhingan, A. K.; Maier, W. F. Homogenous Catalysis with a Heterogenous Pd Catalyst. An Effective Method for the Cyclotrimerization of Alkynes. J. Org. Chem. 1987, 52, 1161-1165.

(9) Li, C.; Chen, T.; Li, B.; Xiao, G.; Tang, W. Efficient Synthesis of Sterically Hindered Arenes Bearing Acyclic Secondary Alkyl Groups by Suzuki-Miyaura Cross-Couplings. Angew. Chemie - Int. Ed. 2015, 54, 3792-3796.

(10) Zhao, Q.; Li, C.; Senanayake, C. H.; Tang, W. An Efficient Method for Sterically Demanding Suzuki-Miyaura Coupling Reactions. Chem. - A Eur. J. 2013, 19, 2261-2265.

(11) Robinson, J. M.; Sakai, T.; Okano, K.; Kitawaki, T.; Danheiser, R. L. Formal [2+2+2] Cycloaddition Strategy Based on an Intramolecular Propargylic Ene Reaction/Diels-Alder Cycloaddition Cascade. $J$. Am. Chem. Soc. 2010, 132, 11039-11041.

Janvier, P.; Bienaymé, H.; Zhu, J. A FiveComponent Synthesis of Hexasubstituted Benzene. Angew. Chemie Int. Ed. 2002, 41, 42914294.

(13) Maimone, T. J.; Milner, P. J.; Kinzel, T.; Zhang, Y.; Takase, M. K.; Buchwald, S. L. Evidence for in Situ Catalyst Modification during the PdCatalyzed Conversion of Aryl Triflates to Aryl Fluorides. J. Am. Chem. Soc. 2011, 133, 1810618109.

Milner, P. J.; Maimone, T. J.; Su, M.; Chen, J.; Müller, P.; Buchwald, S. L. Investigating the Dearomative Rearrangement of Biaryl PhosphineLigated Pd(II) Complexes. J. Am. Chem. Soc. 2012, 134, 19922-19934.

Fors, B. P.; Buchwald, S. L. A Multiligand Based Pd Catalyst for C-N Cross-Coupling Reactions. J. Am. Chem. Soc. 2010, 132, 15914-15917.

Endo, Y.; Songkram, C.; Ohta, K.; Kaszynski, P.; 
Yamaguchi, K. Distorted Benzene Bearing Two Bulky Substituents on Adjacent Positions: Structure of 1,2-Bis(1,2-Dicarba-ClosoDodecaboran-1-yl)Benzene. Tetrahedron Lett. 2005, 46, 699-702.

Dennis, J. M.; White, N. A.; Liu, R. Y.; Buchwald, S. L. Breaking the Base Barrier: An ElectronDeficient Palladium Catalyst Enables the Use of a Common Soluble Base in C-N Coupling. J. Am. Chem. Soc. 2018, 140, 4721-4725.

(18) Lee, H. G.; Milner, P. J.; Colvin, M. T.; Andreas, L.; Buchwald, S. L. Structure and Reactivity of [(L·Pd)N $\cdot(1,5$-Cyclooctadiene $)](n=1-2)$ Complexes Bearing Biaryl Phosphine Ligands. Inorganica Chim. Acta 2014, 422, 188-192.

Ingoglia, B. T.; Buchwald, S. L. Oxidative Addition Complexes as Precatalysts for CrossCoupling Reactions Requiring Extremely Bulky
Biarylphosphine Ligands. Org. Lett. 2017, 19, 2853-2856.

Lee, H. G.; Milner, P. J.; Buchwald, S. L. An Improved Catalyst System for the Pd-Catalyzed Fluorination of (Hetero)Aryl Triflates. Org. Lett. 2013, 15, 5602-5605.

Köllhofer, A.; Plenio, H. Homogeneous Catalysts Supported on Soluble Polymers: Biphasic Sonogashira Coupling of Aryl Halides and Acetylenes Using MeOPEG-Bound PhosphinePalladium Catalysts for Efficient Catalyst Recycling. Chem. - A Eur. J. 2003, 9, 1416-1425.

(22) Olsen, E. P. K.; Arrechea, P. L.; Buchwald, S. L. Mechanistic Insight Leads to a Ligand Which Facilitates the Palladium-Catalyzed Formation of 2-(Hetero)Arylaminooxazoles and 4(Hetero)Arylaminothiazoles. Angew. Chemie Int. Ed. 2017, 56, 10569-10572.

\section{Graphical Abstract:}
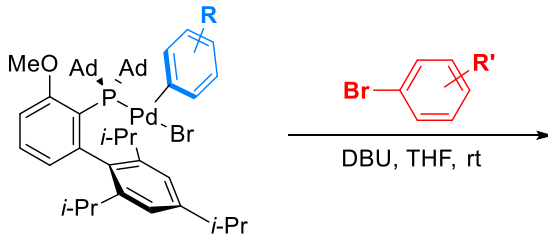

DBU, THF, rt

-Double Pd-Mediated Rearrangement -Strained Hexasubstituted Products Accessible

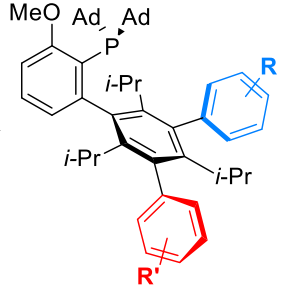

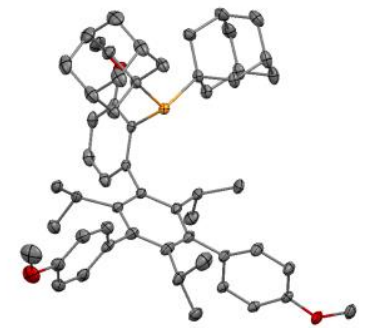

